\title{
Maintenance of strains of Campylobacter jejuni in laboratories after use of cryoprotectors and pre-treatment of stress
}

\section{Manutenção de cepas de Campylobacter jejuni em laboratório após uso de crioprotetores e pré-tratamento de estresse}

\author{
Roberta Torres de $\mathrm{Melo}^{1 *}$; Mariela Moura Carreon²; Guilherme Paz Monteiro ${ }^{3}$; \\ Eliane Pereira Mendonça ${ }^{4}$; Phelipe Augusto Borba Martins Peres ${ }^{3}$; \\ Raquelline Figueiredo Braz ${ }^{5}$; Fernanda Aparecida Longato dos Santos ${ }^{5}$; \\ Daise Aparecida Rossi ${ }^{1}$
}

\begin{abstract}
This study evaluated the feasibility and the production of transcripts of $\operatorname{sodB}, p 19, \mathrm{ciaB}$ and $d n a J$ genes in strains of Campylobacter jejuni ATCC 33291, NCTC 11351, and 2383 IAL stored in whole UHT milk and or neopepton $+12 \%$ glycerol, submitted or not to pre-treatments at $4{ }^{\circ} \mathrm{C}$ or $10^{\circ} \mathrm{C}$ for 30 minutes. The analyzes were performed immediately after freezing in liquid nitrogen (day 0 ) and after maintenance for 30,60 , and 90 days at $-20^{\circ} \mathrm{C}$. The viability was evaluated by the traditional culture method and the production of transcripts by the RT-PCR technique. The quantification was only possible on the first day of analysis (day 0 ) and presented a mean of $3.0 \times 10^{7} \mathrm{CFU}$, and in the other periods of storage the strains presented confluent growth, not allowing their enumeration. The results indicated that whole UHT milk was more adequate for cryopreservation than the use of neopepton $+12 \%$ glycerol. The use of pre-treatments combined with the use of UHT milk as a cryoprotective medium stabilized the cells in order to transcribe the $c i a B$, dnaJ, sodBand $p 19$ genes in the strains maintained under $-20^{\circ}$ for 30 to 60 days, indicating that they are more suitable methods for the maintenance of strains in the laboratory. Key words: Campylobacteriosis. Cryopreservation. RT-PCR. Virulence.
\end{abstract}

\section{Resumo}

Este estudo avaliou a viabilidade e a produção de transcritos dos genes $\operatorname{sodB}, p 19$, ciaB e dnaJ em cepas de Campylobacter jejuni ATCC 33291, NCTC 11351 e 2383 IAL armazenadas em leite integral UHT e / ou neopeptona $+12 \%$ glicerol, submetidas ou não a pré-tratamentos a $4^{\circ} \mathrm{C}$ ou $10^{\circ} \mathrm{C}$ durante 30 minutos. As análises foram realizadas imediatamente após o congelamento em nitrogênio líquido (dia 0) e após a manutenção por 30,60 e 90 dias à $-20^{\circ} \mathrm{C}$. A viabilidade foi avaliada pelo método tradicional de cultura e a produção de transcritos, pela técnica de RT-PCR. A quantificação só foi possível no primeiro dia de análise (dia 0) e apresentou uma média de 3,0 x 107 UFC, e nos demais períodos de armazenamento as cepas apresentaram crescimento confluente, não permitindo sua enumeração. Os resultados indicaram que o leite integral UHT foi mais adequado para criopreservação em relação ao

\footnotetext{
1 Prof $^{\text {as }} \operatorname{Dr}^{\text {as }}$, Universidade Federal de Uberlândia, UFU, Uberlândia, MG, Brasil. E-mail: roberta-melo@hotmail.com; daise. rossi@ufu.br

2 Prof ${ }^{a}$, Universidade do Triângulo Mineiro, UNITRI, Uberlândia, MG, Brasil. E-mail: marielasmoura@yahoo.com.br

3 Discentes de Pós-Graduação, UFU, Uberlândia, MG, Brasil. E-mail: guil.paz@hotmail.com; lipe-peres1@hotmail.com

4 Prof ${ }^{a}$, Universidade de Uberaba, UNIUBE, Uberaba, MG, Brasil. E-mail: eliane_vet@yahoo.com.br

Médicas Veterinárias e Zootecnistas, UFU, Uberlândia, MG, Brasil. E-mail: 1linevet@gmail.com; fe.longato@hotmail.com

* Author for correspondence
} 
uso de neopeptona $+12 \%$ glicerol. A utilização de pré-tratamentos combinados com o uso de leite UHT como meio crioprotetor estabilizou as células para transcrever os genes $c i a B, \operatorname{dnaJ} \operatorname{sodB}$ e $p 19$ nas cepas mantidas abaixo de $-20^{\circ}$ por 30 a 60 dias, indicando que são métodos mais adequados para a manutenção de cepas em laboratório.

Palavras-chave: Campilobacteriose. Criopreservação. RT-PCR. Virulência.

Campylobacter has long been considered a fragile, environmentally sensitive microorganism (FDA, 2012), but studies have demonstrated its ability to adapt to environmental stress, which may aid its survival in adverse conditions, such as variations in temperature, atmosphere, and even hygienic processes. In addition, Campylobacter can modulate its transcriptome to alter virulence expression according to changes in environmentalconditions (MELO et al., 2013; 2017).

Among the difficulties involved in the research of Campylobacter, the biological characteristics of this microorganism, makes it particularly distinct from most bacterial enteropathogens, requiring unique conditions for its isolation and identification. There is also difficulty in the study of this agent by the absence of procedures to maintain the viability of strains isolated in laboratories for later studies. Most of the conservation protocols for this bacterium use the cryoprotection method, however Campylobacter presents sensitivity to cold stress, which is dependent on several factors, including temperature variation, freezing speed, culture medium used as cryoprotectant, the strain itself, and the duration of storage (BEALES, 2004).

The application of stress treatments prior to cell freezing, such as cold shock, may result in changes in the cytoplasmic membrane composition and in the induction of some stress proteins. These changes in the cell are associated with increased freezing tolerance (ZHANG et al., 2013).

The maintenance of $C$. jejuni strains isolated from food and human patients is fundamental for further studies, the results of which may aid in the understanding of its pathogenesis as well as in epidemiological studies. Thus, in view of the current international requirements related to the control of this microorganism (CE, 2017), it is essential to expand knowledge, including on the forms of efficient cryopreservation, due to the difficulties of working with this agent in in vitro conditions. This study aimed to verify the viability, production of transcripts by virulence genes, and stress adaptation in three strains of $C$. jejuni, with and without two pre-treatments in two cryoprotectants after freezing at $-20^{\circ} \mathrm{C}$ for up to 90 days, as a way to store strains in the laboratory.

Three reference strains of $C$. jejuni (ATCC 33291, NCTC 11351, and IAL 2383) were used. After reactivation, the ability of these strains to produce transcripts of the ciaB, dnaJ, p19, and $\operatorname{sodB}$ genes, associated with virulence and thermal tolerance, was confirmed.

Each cryoprotectant tested (whole UHT milk and neopepton $+12 \%$ glycerol) was initially prepared in a volume of $300 \mathrm{~mL}$ and distributed in three equal portions. Each of them was inoculated with $10^{8}$ CFU.mL $\mathrm{m}^{-1}$ of each one of the strains, homogenized, and distributed $(1.5 \mathrm{~mL})$ in 12 sterile microtubes. In all, 24 microtubes (12 with UHT whole milk and 12 with neopepton $+12 \%$ glycerol) were submitted to three treatments: 1) immediate freezing by immersion in liquid nitrogen for 10 seconds (control); 2) thermal stress $\left(4^{\circ} \mathrm{C} /\right.$ 30 minutes) and freezing in liquid nitrogen for 10 seconds; 3$)$ thermal stress $\left(10^{\circ} \mathrm{C} / 30\right.$ minutes $)$ and freezing in liquid nitrogen for 10 seconds. A sample of each treatment was immediately analyzed and the others frozen at $-20^{\circ} \mathrm{C}$ and analyzed after 30,60 , and 90 days.

In each period, the viability of the strains by the traditional culture method with pre-enrichment and 
the count of cells in CFU.mL ${ }^{-1}$ (ISO10272-1, 2006) were verified, separately and in triplicate, besides the variation in the capacity of produced transcripts. Samples were thawed at room temperature.

For counting, serial decimal dilutions up to $10^{-7}$ were performed. In parallel, the presence / absence analysis was performed with pre-enrichment in Bolton broth followed by inoculation in CCDA agar (Oxoid $\AA$ ).

The ability to produce virulence and resistance transcripts under stress conditions (genes ciaB - cell invasion, dnaJ - tolerance to high temperatures, $p 19$ - acquisition of iron, and $\operatorname{sod} B$ - oxidative stress in cold shock) was verified by RT- PCR, after counting and presence or absence analysis.

To obtain the RNA, each of the isolates was seeded in four plates of CCDA (Oxoid $囚$ ) by the filling method. After incubation in a microaerophilic atmosphere (Probac $\AA$ ) for 48 hours at $37^{\circ} \mathrm{C}$, all colonies formed on the plates were transferred to microtubes containing $2 \mathrm{~mL}$ of $0.85 \% \mathrm{NaCl}$ solution (Synth ${ }^{\circledR}$ ) and the procedures were performed to extract the RNA (MELO et al., 2013).

Reverse transcription was performed in each sample using $1 \mu \mathrm{L}$ of total RNA (200ng $/ \mu \mathrm{L}), 10 \mathrm{U}$ RNase inhibitor, 40 $\mu$ MMLV-RT (AmershamBiosciences), 1X MMLV-RT Buffer (AmershamBiosciences), 200 $\mu \mathrm{L}$ dNTPs (dGTP, dATP, dTTP and dCTP), and 126 picomoles of hexameric oligonucleotides as random primers (Invitrogen $($ ). The final volume of each reaction was completed to $20 \mu \mathrm{L}$ with DEPC-treated water (Invitrogen ${ }^{\circledR}$ ). The solution was placed in a thermal cycler (Eppendorff®) at $37^{\circ} \mathrm{C}$ for one hour. Control reactions were performed for the verification of possible exogenous contaminants. The cDNA was stored at $-20^{\circ} \mathrm{C}$ for further amplification.

After RNA transcription, $3 \mu \mathrm{L}$ of the cDNA was used in a final volume for the amplification reaction of $25 \mu \mathrm{L}$, composed of: $0.625 \mathrm{U}$ of Taq DNA Polymerase, $5 \mathrm{mM}$ of $\mathrm{MgCl}_{2}, 200 \mu \mathrm{L}$ of dNTPs and 4 picomoles of each primer (Invitrogen $\left.{ }^{\circledR}\right)$. To verify the production of transcripts the pairs of primers ciaB,dnaJ, p19, and $\operatorname{sodB}$ (LI et al., 2008; BIRK et al., 2012) were used. The amplification was performed in a thermal cycler (Eppendorff $\AA$ ), following the cycles: 1 initial cycle at $94^{\circ} \mathrm{C}$ for 3 minutes; 45 cycles of amplification in 3 steps: $i$. denaturation at $94{ }^{\circ} \mathrm{C}$ for 15 seconds; ii. annealing at $51^{\circ} \mathrm{C}$ for $20 \mathrm{~seconds}$; iii. extension at $72{ }^{\circ} \mathrm{C}$ for 20 seconds; finishing with a final extension cycle at $72^{\circ} \mathrm{C}$ for 3 minutes. Descriptive statistical analysis and Fisher's exact test were used for comparative purposes using Graph Pad Prism 7.0 software.

The quantification of $C$. jejuni stored in the two cryoprotectants was only possible in samples immediately analyzed after freezing in liquid nitrogen for 10 seconds before storage at $-20^{\circ} \mathrm{C}$. In these strains, the number of cells ranged from $6.0 \times 10^{6}$ to $1.0 \times 10^{8} \mathrm{CFU}$, with an average of $3.0 \times 10^{7}$ CFU. $\mathrm{mL}^{-1}$. After storage for 30,60 , and 90 days, the colonies grew confluent, forming a film and them impossible to count.

Considering the three strains studied, of the 36 samples kept in whole UHT milk, 33 (91.7\%) presented growth. This value differed significantly $(p=0.0004)$ compared to the samples kept in neopepton $+12 \%$ glycerol, which presented viability in 52.8\% (19/36) of the samples. In general, for all strains tested, it was observed that the use of whole UHT milk as cryoprotectant contributed more effectively to the maintenance of viability, regardless of treatment and time. The exception is strain IAL 2383, which was able to maintain its viability over time in both cryoprotectants. In addition, the viability of $C$. jejuni strains was not influenced by the use of pre-treatments (Table 1). 
Table 1. Viability of $C$. jejuni strains ATCC 33292, NCTC 11351, and IAL 2383 in two cryoprotectants after three different treatments and subsequent freezing at $-20^{\circ} \mathrm{C}$ for $0,30,60$ and 90 days.

\begin{tabular}{ccccccccccc}
\hline \multicolumn{10}{c}{ Campylobacter jejuni tested strains $^{1}$} \\
\hline & \multicolumn{1}{c}{ ATCC 33291 } & \multicolumn{3}{c}{ NCTC 11351 } & \multicolumn{3}{c}{ IAL 2383 } \\
\hline Cryoprotectants & Days & Control $^{2}$ & $4{ }^{\circ} \mathrm{C}^{3}$ & $10^{\circ} \mathrm{C}^{4}$ & Control $^{2}$ & $4{ }^{\circ} \mathrm{C}^{3}$ & $10^{\circ} \mathrm{C}^{4}$ & Control $^{2}$ & $4^{\circ} \mathrm{C}^{3}$ & $10^{\circ} \mathrm{C}^{4}$ \\
\hline \multirow{3}{*}{ Whole UHT } & 0 & $3 / 3$ & $3 / 3$ & $3 / 3$ & $3 / 3$ & $3 / 3$ & $3 / 3$ & $3 / 3$ & $3 / 3$ & $3 / 3$ \\
Milk & 30 & $3 / 3$ & $3 / 3$ & $3 / 3$ & $3 / 3$ & $3 / 3$ & $3 / 3$ & $3 / 3$ & $3 / 3$ & $3 / 3$ \\
& 60 & $3 / 3$ & $3 / 3$ & $3 / 3$ & $3 / 3$ & $3 / 3$ & $3 / 3$ & $3 / 3$ & $3 / 3$ & $3 / 3$ \\
& 90 & $3 / 3$ & $3 / 3$ & $3 / 3$ & $3 / 3$ & $3 / 3$ & $3 / 3$ & $0 / 3$ & $0 / 3$ & $0 / 3$ \\
Neopepton + & 0 & $3 / 3$ & $3 / 3$ & $3 / 3$ & $3 / 3$ & $3 / 3$ & $3 / 3$ & $3 / 3$ & $3 / 3$ & $3 / 3$ \\
$12 \%$ glycerol & 60 & $0 / 3$ & $0 / 3$ & $0 / 3$ & $0 / 3$ & $3 / 3$ & $0 / 3$ & $3 / 3$ & $3 / 3$ & $3 / 3$ \\
& 0 & $0 / 3$ & $0 / 3$ & $0 / 3$ & $0 / 3$ & $0 / 3$ & $0 / 3$ & $3 / 3$ & $3 / 3$ & $3 / 3$ \\
& 90 & $0 / 3$ & $0 / 3$ & $0 / 3$ & $0 / 3$ & $0 / 3$ & $0 / 3$ & $3 / 3$ & $3 / 3$ & $3 / 3$ \\
\hline
\end{tabular}

${ }^{1}$ The total of C. jejuni tested strains: 36

${ }^{2}$ Treatment 1 (control): freezing by immersion in liquid nitrogen for 10 seconds. Number of strains tested / number of viable strains after treatment and storage at $0,30,60$ and 90 days.

${ }^{3}$ Treatment 2: thermal stress $\left(4^{\circ} \mathrm{C} / 30\right.$ minutes $)$ and freezing in liquid nitrogen for 10 seconds. Number of strains tested / number of viable strains after treatment and storage at $0,30,60$ and 90 days.

${ }^{4}$ Treatment: thermal stress $\left(10^{\circ} \mathrm{C} / 30\right.$ minutes $)$ and freezing in liquid nitrogen for 10 seconds. Number of strains tested / number of viable strains after treatment and storage at $0,30,60$ and 90 days.

In total, 46 samples that had viable cells for the production of transcripts were analyzed, 15 of them from the ATCC strain (12 from whole UHT milk and three from neopepton $+12 \%$ glycerol), 20 from the IAL strain (eight from milk and 12 from glycerol), and 11 from NCTC (six of milk and five of glycerol).

The transcription of the studied genes underwent variations over the storage time. In general, strains maintained in milk and submitted to pre-treatments were able to transcribe all genes in subsequent analyzes, even in those that did not present transcripts in the initial periods (immediately after freezing in liquid nitrogen for 10 seconds). The strains were able to preserve or adapt back to the initial condition of transcription production for $c i a B$, dnaJ, sodBand $p 19$ when whole UHT milk was used as a cryoprotectant associated with pretreatment (4 or $10^{\circ} \mathrm{C}$ ) (Table 2).

Another fact in common to all strains was the similarity in the results for the $\operatorname{sod} B$ and $p 19$ genes as well as for $c i a B$ and $d n a J$ in each of the cryoprotectants.

Regarding to $C$. jejuni ATCC, it was observed that for the $c i a B$ and $d n a J$ genes, independent of the condition (cryoprotectant or use of pre-treatments), the bacterium maintained its ability to transcribe them. For $\operatorname{sod} B$ and $p 19$, absence of transcripts on day 0 was observed for the neopepton-preserved control group and the pre-treated milk samples at $4^{\circ} \mathrm{C}$. For the samples conserved in neopepton it was not possible to evaluate the subsequent behavior since no viable cells were recovered.

For the NCTC 11351 strain conserved in milk, the transcription of all genes was maintained when subjected to pre-treatments, except for the control groups, where there was no transcription for the $\operatorname{sodB}$ and $p 19$ genes. In contrast, transcription in those stored in glycerol was inhibited after freezing at $-20^{\circ} \mathrm{C}$, except for the control group, in which the production of transcripts for $c i a B$ and dnaJ was conserved. 


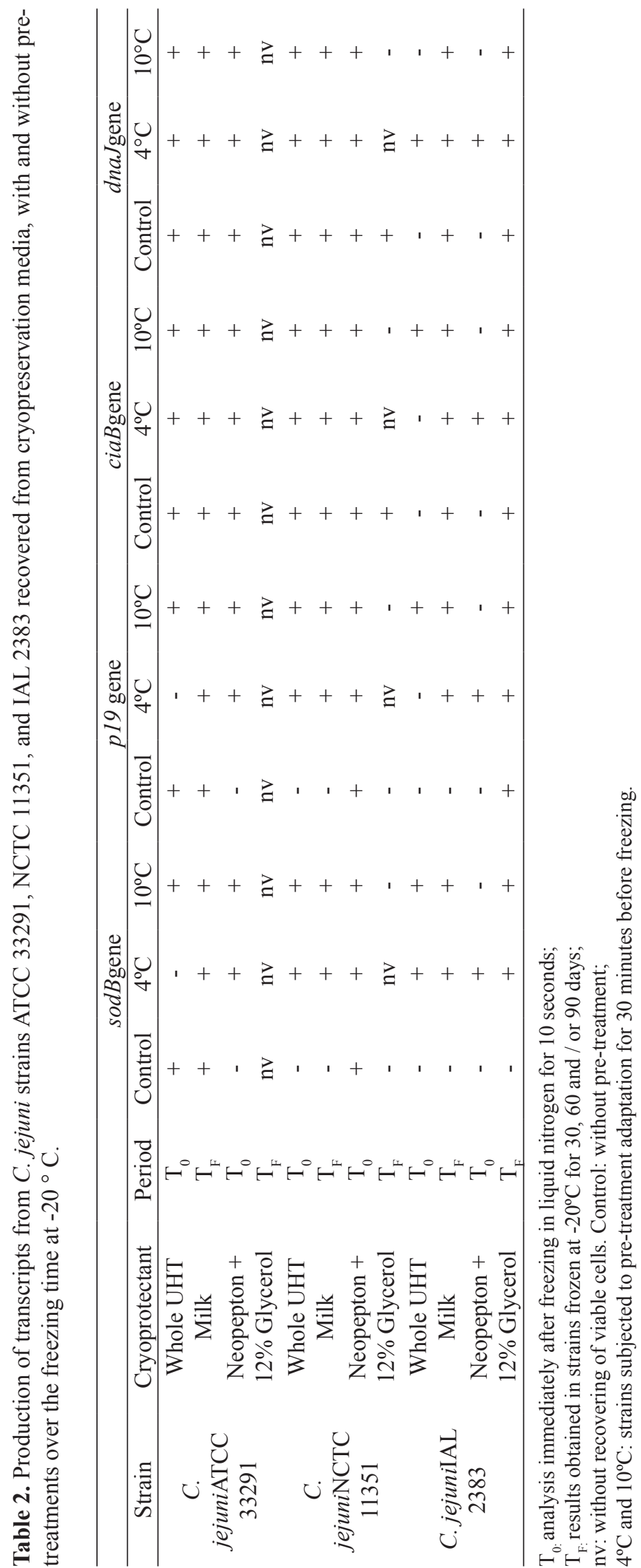


In IAL 2383, under all pre-treatment conditions its transcription ability was maintained or its transcriptome altered to produce the transcripts after maintenance under freezing at $-20^{\circ} \mathrm{C}$ for 30 days or more. This condition was observed for the $c i a B$ and $d n a J$ genes in the two pre-treatments, independent of the cryoprotectant. Differential behavior was observed for the control group samples maintained in milk for the $\operatorname{sodB}$ and $p 19$ genes and for the control group maintained on neopepton $+12 \%$ glycerol for the $\operatorname{sod} B$ gene.

The correlation in the production of transcripts of the $\operatorname{sodB}$ and $p 19$ genes, as well as that of $\operatorname{ciaB}$ and $d n a J$ was not maintained for the cryopreserved samples in milk with pretreatment at $4^{\circ} \mathrm{C}$.

The presence of confluent colonies, forming a film, also called a "swimming" veil, making it impossible to count shows the difficulty of enumeration of Campylobacter after its maintenance under freezing, and the importance of pre-enrichment to attest to the presence / absence of these micro-organisms.

The higher number of viable samples recovered from the UHT-stored strains was expected since the milk had a protective effect due to the action of fat in stabilizing the membrane fluidity of the bacterial cell and the contribution of calcium to the cellular enzymatic stability (CARVALHO et al., 2004).

The survival and gene transcription capacity of the IAL 2383 strain to the final periods in both cryoprotectants may be related to the intrinsic characteristics of this strain isolated from an outbreak in humans, and that probably presents a greater adaptability. A study by Fonseca et al. (2014) with the strain IAL 2383 showed that due to the virulence characteristics, the strain can be used as a useful model in studies related to pathogenicity. The strain-dependent variation identified in the study shows the need for tests on other wild-type isolates of Campylobacter to confirm the efficiency of treatments in cell stability.
In the present study, no difference was observed in the stability of the strains after the use of the two pre-treatments, unlike the study carried out by LEE (2004) with strains of Lactococcus lactis, which showed that the pre-treatment at temperatures different from the optimum temperature for development of the microorganism increased its survival for long periods.

Environmental conditions may generate considerable variation in the gene expression capacity of C. jejuni. According to Mourik (2011), C. jejuni developed a repertoire of specific mechanisms allowing for rapid metabolic adaptation, besides the changes in growth and behavior according to the different environments. The use of milk and pretreatments allowed the maintenance of the original transcription characteristics of the strains, probably due to the protective effect of the milk and the use of pre-treatments at temperatures of 4 or $10^{\circ} \mathrm{C}$, which helps to stabilize the cell before freezing at $-20{ }^{\circ} \mathrm{C}$ (ZHANG et al., 2013).

The correlation in the transcription of $\operatorname{sodB}$ and $p 19$ genes has been described previously (PALYADA, 2004). The $\operatorname{sodB}$ gene participates in the response to oxidative stress and there is a clear link between this condition and iron, since the increase in iron concentration increases the expression of genes in defense of this type of stress. As for the $c i a B$ and $d n a J$ genes, previous studies have also found this relationship (MELO et al., 2013; MONTEIRO et al., 2015).

We conclude that the use of whole UHT milk as cryoprotectant was more efficient in maintaining the viability of the strains when compared to the use of neopepton $+12 \%$ glycerol.

The use of pre-treatments at $4^{\circ} \mathrm{C}$ or $10^{\circ} \mathrm{C}$ for 30 minutes combined with the use of whole UHT milk as a cryoprotectant medium stabilized the cell in order to transcribe the $c i a B, d n a J, \operatorname{sodB}$ and $p 19$ genes in the strains maintained under freezing at $-20^{\circ}$ for 60 days, indicating that they are suitable methods for the maintenance of the strains in laboratory. 


\section{References}

BEALES, N. Adaptation of microorganism to cold temperatures, weak acid preservatives, low $\mathrm{pH}$, and osmotic stress: a review. Comprehensive Reviews in Food Science and Food Safety, Gloucestershire, v. 3, n. 1, p. 1-20, 2004. DOI: 10.1111/j.1541-4337.2004.tb00057.x

BIRK, T.; WIK, M. T.; LAMETSCH, R.; KNOCHEL, $\mathrm{S}$. Acid stress response and protein induction in Campylobacter jejuni isolates with different acid tolerance. BioMed Central Microbiology, Frederiksberg, v. 12, n. 174, p.1-13, 2012. DOI: 10.1186/1471-2180-12174

CARVAlHO, A. S.; SILVA, J.; HO, P.; TEIXEIRA, P.; MALCATA, F. X.; GIBBS, P. Effects of various sugars added to growth and drying media upon thermotolerance and survival throughout storage of freeze-dried Lactobacillus delbrueckii ssp. bulgaricus. BiotechnologyProgress, Porto, v. 20, n. 1, p. 248-254, 2004. DOI: $10.1021 / \mathrm{bp} 034165 \mathrm{y}$

COMUNIDADE EUROPÉIA - CE/EU. Regulamento (UE) 2017/1495 da Comissão de 23 de agosto de 2017 que altera o Regulamento (CE) n.o 2073/2005 no que diz respeito à Campylobacter em carcaças de frangos de carne. Cidade: Bruxelas. Jornal Oficial da União Europeia, 2017.

FONSECA, B. B.; ROSSI, D. A.; MAIA, C.A.; NALEVAIKO, P. C.; MELO, R. T.; CUCCATO, L.P.; BELETTI, M.E. Characterization of the virulence, grow themperature and antibiotic resistance of the Campylobacter jejuni IAL 2383 strain isolated from humans. Brazilian Journal of Microbiology, São Paulo, v. 45 , n. 1, p. 271-274, 2014. DOI: 10.1590/S151783822014000100039

FOOD AND DRUG ADMINISTRATION - FDA. Department of Health and Human Services. Campylobacter jejuni. In: Bad bug book: foodborne pathogenic microorganisms and natural toxins handbook. Maryland: FDA, 2012. Available at: http:// www.fda.gov/Food/FoodSafety/FoodborneIllness/ FoodborneIllnessFoodbornePathogensNaturalToxins/ BadBugBook/ucm070024.htm. Accessed at: 02 mar. 2019 .

INTERNATIONAL STANDARDS ORGANIZATION ISO 10272-1: Microbiology of food and animal feeding stuffs - horizontal method for detection and enumeration of Campylobacter spp. - Part 1: detection method. Genebra: ISO, 2006.
LEE, K. Cold shock response in Lactococcuslactiss sp. diacetylactis: a comparison of the protection generated by brief pre-treatment at less severe temperatures. Process Biochemistry, Kwangju, v. 39, n. 12, p. 22332239, 2004. DOI: 10.1016/j.procbio.2003.11.025

LI, Y. P.; INGMER, H.; MADSEN, M.; BANG, D. D. Cytokine responses in primary chicken embryo intestinal cells infected with Campylobacter jejuni strains of human and chicken origin and the expression of bacterial virulence-associated genes. BMC Microbiology, Reading, v. 8 , n. 107 , p. $1-10,2008$. DOI: $10.1186 / 1471-2180-8-$ 107

MELO, R. T.; MENDONÇA, E. P.; MONTEIRO, G. P.; SIQUEIRA, M. C.; PEREIRA, C. B.; PERES, P. A. B. M.; FERNANDEZ, H.; ROSSI, D. A. Intrinsican dextrinsicas pectson Campylobacter jejuni biofilms. Frontiers Microbiology, Uberlândia, v. 18, n. 8, p. 1-15, 2017. DOI: 10.3389/fmicb.2017.01332

MELO, R. T.; NALEVAIKO, P. C.; MENDONÇA, E. P.; BORGES, L. W.; FONSECA, B. B.; BELETTI, M. E.; ROSSI, D. A. Campylobacter jejuni strains isolated from chicken meat harbor several virulence factors and represent a potential risk to humans. Food Control, Vurrey, v. 33, n. 1, p. 227-231, 2013. DOI: 10.1016/j. foodcont.2013.02.032

MONTEIRO, G. P.; MELO, R. T.; NALEVAIKO, P. C.; MENDONÇA, E. P.; FONSECA, B. B.; ROSSI, D. A. Sobrevivência de Campylobacter jejuni em leite pasteurizado e UHT artificialmente contaminados, sob refrigeração. Revista do Instituto Adolfo Lutz, São Paulo, v. 74, n.3, p. 280-285, 2015.

MOURIK, A. V. Host adaptation mechanisms and transcriptional regulationin Campylobacter jejuni. 2011. Thesis (Doctorate in Infection and Immunity) - Center Utrecht, Universiteit Utrecht, Utrecht.

PALYADA, K. Response of Campylobacter jejuni to iron and hydrogen peroxide. 2004. Thesis (Doctorate in Veterinary Pathology) - The Oklahoma State University, Oklahoma.

ZHANG, G.; FAN, M.; QIAN, L.V.; LI, Y.; LIU, Y.; ZHANG, S.; ZHANG, H. The effect of cold, acid and ethanol shocks on synthesis of membrane fatty acid, freeze-drying survival and malolactic activity of Oenococcusoeni. Annals of Microbiology, Milan, v. 63, n. 2, p. 477-485, 2013. DOI: $10.1007 / \mathrm{s} 13213-012-0492-\mathrm{X}$ 
